\title{
遺跡の公園化のための遺跡情報データベースの構築
}

\section{Construction of the Excavation Information Database Systems for Historical Park Planning}

\author{
藤田英樹 ${ }^{*}$ 川口摩利夫 ${ }^{* *}$ 上島晃嗣 ${ }^{* * *}$ 鈴木雅和 ${ }^{* * * *}$ \\ Hideki FUJITA Mario KAWAGUCHI Koji UESHIMA Masakazu SUZUKI
}

\begin{abstract}
摘要：本研究は．国営および県営公園として利用が決定している吉野ヶ里歴史公園をケーススタディ
とし，寈跡情報と公園情報の共有化ための手法と具体的構造を考察したものである。これらの情報は 取り扱う組織が複数にまたがるため, 一貫した情報管理が難しくなっている。そこで, 発掘情報の公 園化における有効利用を目的とした発掘情報データベースの構築を行った。これは，インターネット による発掘情報の発信者・利用者間の情報共有化を目指したものである。その結果, 発掘現場におい て得られた遺跡情報を公園計画・管理・運営・展示計画などにおいても利用できる可能性を開いたと いえる。データ更新の簡素化とデータ構造の汎用化が今後の課題である。
\end{abstract}

\section{1.はじめに}

遺跡はその土地にかつて存在していた文化・生活などに関する 時系列的な情報を内在した空間的資源であり, 研究者に学術的な 価値のある情報を与えるだけではなく，そこを訪れる観光客や， そこに生活している一般市民にとっても地域の歴史を追体験でき る場として重要な存在である。実際, 話題性のある遺跡が発掘さ れた場合には，年間で百万人を越える来訪者をみることもある。 しかし，遺跡における発掘調査成果の記録と整理の方法は, どの ような立地においても実行可能であるように，その方法は手作業 を中心として行われてきた。そのため, 情報の作成・整理・解析 は発掘作業から相当遅れた形にならざるを得ず, 情報相互の関連 を探るような複雑な解析も困難である。このような現状に対し, 考古学にコンピュータを活用しようという気運が芽生えている

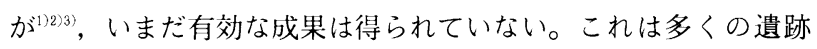
が開発に伴って発見されるものであり, 発掘の時間的余裕が無い ことに加え, 地方自治体の教育・文化行政の限られた予算之人員 で発掘が行われるため情報化の余裕が無いこと, 有効な情報化の 方法論が開発されていないことなど，多くの要因が考えられる。 このように，発掘調查における情報化の枠組みが十分でない中で, 遺跡を公園として保存していく動きが活発化しており, また, 佐 賀県の吉野ヶ里遺跡や青森県の三内丸山遺跡のように大規模な遺 跡を都市公園として保存・展示していこうという動きもみられる ようになってきている。

\section{2. 本研究の目的亡論文の位置づけ}

筆者らは, 国営・県営公園として事業決定している吉野ヶ里遺 跡公園をケーススタディとして, 遺跡情報と公園情報の共有化に おける一連の方法論を提案する研究を続けている。これは, 遺跡 の発掘調查に始まり, 公園化における調査・計画・設計・施工・ 管理・運営へとつながっていく一連のプロセスにおける情報共有 の枠組み構築を目的としたものである。遺跡は 3 次元の空間的情 報のみならず, 時間的推移に関わる情報を併せ持つことから，こ の情報化には GIS (Geographic Information System : 地理 情報システム）を中心とすることが有効であると考えられる。そ こで, 一連のプロセスにおける具体的な過程を明らかにし, 博物 館における情報計画・情報公開といった面に至るまで遺跡情報が 高度利用される可能性を踏まえて GIS システムの利用を検討し
てゆく。これらの情報化においては遺跡と公園施設の平面・断面 の空間情報に加え, 遺跡の考古学的属性情報, 公園施設の属性情 報を総合的に管理することが必要である ${ }^{4)}$ 。現実的には，公園の 上物を整備する建設省と遺跡を所管する佐賀県教育委員会の双方 が重複や漏れ，矛盾が無く共有できるように情報構造を整理する ととあに，それに基づいた整備を行う必要がある ${ }^{5)} 。$

本論文では，一連の研究の目的である遺跡情報の高度利用にお ける具体的プロセスの提案の第一段階として, 遺跡情報データベー スシステムの構築を試験的に抗こなった。現状において一般的に 用いられている電子化されていない遺跡情報は情報の即時性と応 用性に欠けており，情報の共有において矛盾が発生するおそれが ある。そこで, この電子化されていない遺跡情報を迅速にデジタ ルデー夕化する手法を開発し，コンピュータ上で利用することで 遺跡情報の応用性・汎用性・即時性を持たせることを試みた。ま た，その情報の共有のためにインターネット GIS の技術を用い たデータベースシステムを開発した。これによって, 情報の作成 之利用において重複や矛盾が発生しないシステムにすることを試 みた。

\section{3. 吉野ヶ里歴史公園の情報化における現状把握 \\ （1）吉野ヶ里歴史公園の空間構成}

吉野ヶ里歷史公園は, 図 1 に示すように, 国指定「特別史跡」 の部分と県指定「史跡」の部分とからなる遺跡の中心部およそ 54ha にわたる建設省直轄事業の国営公園部分の周囲を，およそ 63ha にわたる佐賀県事業の県営公園部分が囲む形となっている。 遺跡全体の構造には比較的明瞭な空間区分が確認されており，北 側に南北方向に列をなした蒦棺墓列, 中央東側には吉野ヶ里の首 長が葬られたといわれている墳丘墓や, 弥生時代としては最大の 規模を持つ大型建造物の跡がみられる北内郭など, 弥生時代全般を 通して変化・拡大が断続的にみられる遺跡があるのが明らかとなっ ているが, その全容の解明については調査・研究の途上にある。

\section{（2）遺跡の分布状況}

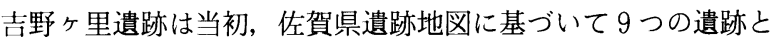
してとらえられていたが, その後の調査においてそれぞれの遺跡 間の関連性が高いことが明らかとなったため, 吉野ヶ里丘陵一帯 に散在する遺跡群を総称して吉野ヶ里遗跡とし，現在 8 地区に区 分して情報が整理されている（図 2 )。さらに，道路や小河川に

*筑波大学大学院芸術学研究科 **川口ソフト開発 ***建設省公園緑地課 ****筑波大学芸術学系 


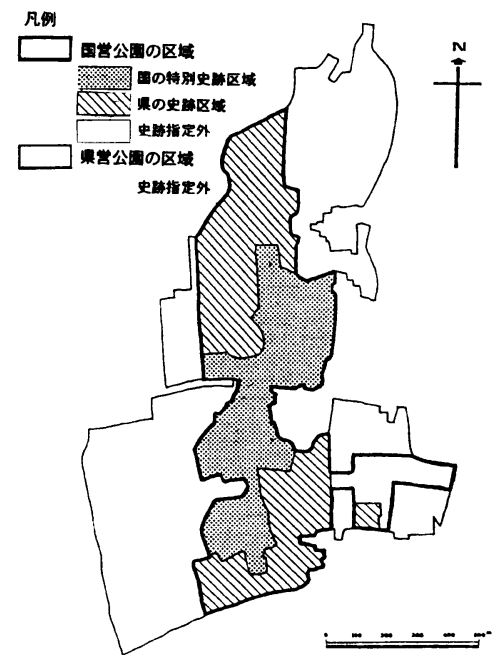

図一 1 吉野ヶ里歴史公園区域図 ${ }^{10}$

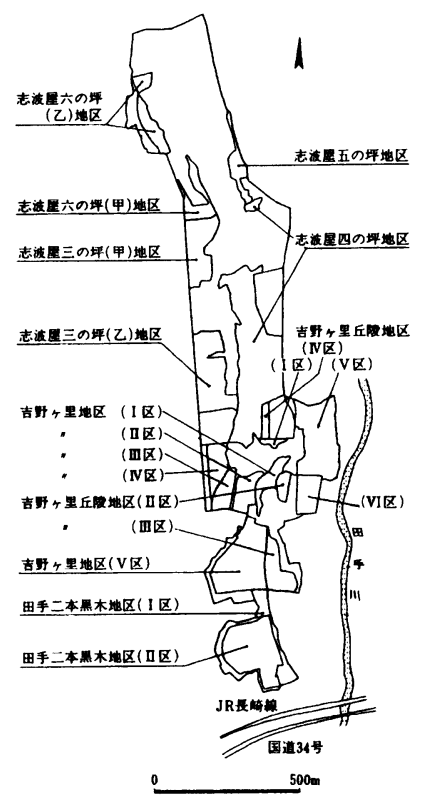

図一２吉野ヶ里遺跡地区位置図"

よって分断された地区は小区（I区，II区など）に分けられてい る。また，これらの地区分けとは別に，国土座標により全体を 20 $\mathrm{m}$ 方眼で地区割り.儿，北東を起点に西へ $\mathrm{AA} ・ \mathrm{AB} ・ \mathrm{AC} ・ ・ ・$ とし, 南へ $1 \cdot 2 \cdot 3 \cdot 4 \cdot \cdots$ とされた。これにより, ある $20 \mathrm{~m}$ 方眼の地区はたとえば AF-34 と定義される。各遺構にはこの 20 $\mathrm{m}$ 四方の地区名を併記し, 整理時の検索の便がはかられ, さらに $20 \mathrm{~m}$ 四方の区域内が $4 \mathrm{~m}$ 四方の 25 小区に分けられ, 詳細調查の 記述に利用されている。遺構の実測などの作業においては $20 \mathrm{~m}$ 方眼のグリッド交点部分に大きな杭が， $4 \mathrm{~m}$ 方眼のグリッド交点 部分には小さい杭が打設される。発掘調査においてはこれらの分 類に対応して, 平板測量によって遣構の配置状況が記録され, 発 掘の進行によって遺構の性格が明らかになり次第, 遺構に番号が つけられ，その遺構番号が配置図と遺構一覧表に記録された。ま た, これらの遺構番号はもっとも大きな地区区分ごとに付されて (るる ${ }^{6}$ 。

\section{（3）遺構・遺物に関する一次情報}

発掘された遺構は各種フィルムサイズの写真による記録ととも に, 縮尺 $1 / 100$ あるいは $1 / 50$ で平板上に記録され，それぞれに 遺構番号が付された。さらに国土座標に従った $20 \mathrm{~m}$ 方眼のグリッ
ド交点による区切りごとに, その内部の遺構検出状況や遺物の出

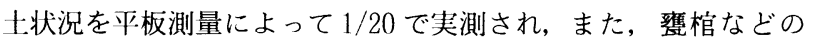
小型の墳墓といった特殊な遺構については $1 / 10$ で個別に実測さ れた。また, 発掘現場では遺構等の実測図が作成されるほか, 遺 構の一覧表や遺物の実測図 (原寸), 遺物整理台帳, 遺構写真台 帳などそれぞれ数干枚オーダーの資料が, 県の教育委員会を中心 に組織された吉野ヶ里遺跡発掘調査事務所において作成されてい る。それらの一次情報の階層的関係を図 3 に示す。

\section{（4）遺跡情報と公園情報の相互関係}

吉野ヶ里遺跡において発掘調査が終了した部分は, 風化・侵食 に対する遺構面保護のために埋め戻した状態にある。さらに，今 後公園として整備する際には, 遺構保護のために $30 \mathrm{~cm}$ 以上の覆 土をして整備を行う方針がとられており，その覆十よりも上位に， 遺構から得られた情報を元にした復元面, あるいは園路等の公園 施設等を整備する。また, 配管などの地下埋設物むこの覆上の範 囲に収まるように計画されている。以上の関係を図 4 に示す。つ まり, 吉野ヶ里歴史公園の空間情報は, 大きく 3 つのレイヤーが オーバーレイしていることになる。このように異なる価值体系を もった複数の層を持っているため, 公園の建設の過程においては, 将来の遺跡再調査の可能性も踏まえて, 遺跡を破壊することがな いように配慮する必要がある。そのためには遺構の正確な位置関 係を把握していることが必要である。

\section{4. 対象範囲}

本データベースは, 吉野ヶ里丘陵第 VI 区と呼ばれる北内郭部 分の範井を対象に作成した。吉野ヶ里遺跡の発掘調查において作 成された情報は表 1 に示したとおりである。これらの資料をスキャ ナで読み込みラスターデー夕化したものを原データとして用いた。 現在吉野ヶ里丘陵第 VI 区の発掘調査は終了しているが，遗物等 の復元作業やその図面化作業が進行中であったため, 遺物等の資 料に関しては完全に網羅しておらず，使用したデータは 1997/11 /13 現在のものである。

\section{表 -1 発掘資料一覧表}

\begin{tabular}{|l|l|}
\hline 資料名 & 記録フォーマット \\
\hline $1 / 100$ 平板記録図 & $\mathrm{A} 2$ 版方眼紙 \\
\hline $1 / 20$ 遺構配置図 & $\mathrm{A} 2$ 版方眼紙 \\
\hline $1 / 1$ 遺物実測図 & $\mathrm{A} 2$ 版方眼紙 \\
\hline 土層図 & $\mathrm{A} 2$ 版方眼紙 \\
\hline 平板図 & $\mathrm{A} 2$ 版方眼紙 \\
\hline 気球写真 & $6 \times 6$ 版 \\
\hline 遺構記録写真 & $35 \mathrm{~mm}$ リバーサル \\
\hline 遺構記録写真 & $35 \mathrm{~mm}$ モノクローム \\
\hline 遺構記録写真 & $6 \times 7$ 版,6x9版,4x5版 \\
\hline
\end{tabular}

5. データ構造とデジタルデータ化の手法

\section{(1) デー夕構造}

本データベースにおけるデータ構造の概念を図 5 に示す。これ らのデータは発掘図面等からパーソナルコンピュータベースで作 成できるようにした。そのため，比較的簡便な手法で紙に書かれ た情報のデジタル化が可能となる。これは専門の情報処理技術者 等がいない遺跡発掘現場等における運用を考えたためである。ま た，公園施設面に関しては現在建設途上の部分もあり，具体的な 部分における計画が変わる可能性があるため, 本システムには組 み込まれてはいない。

\section{（2）地表面デー夕}

地表面データとしては建設省によって 1998 年 2 月 19 日に撮影 された空中写真を元にデジタルオルソフォトデータにコンバート して作成されたラスター画像を地表面データカバレッジ（現在の 

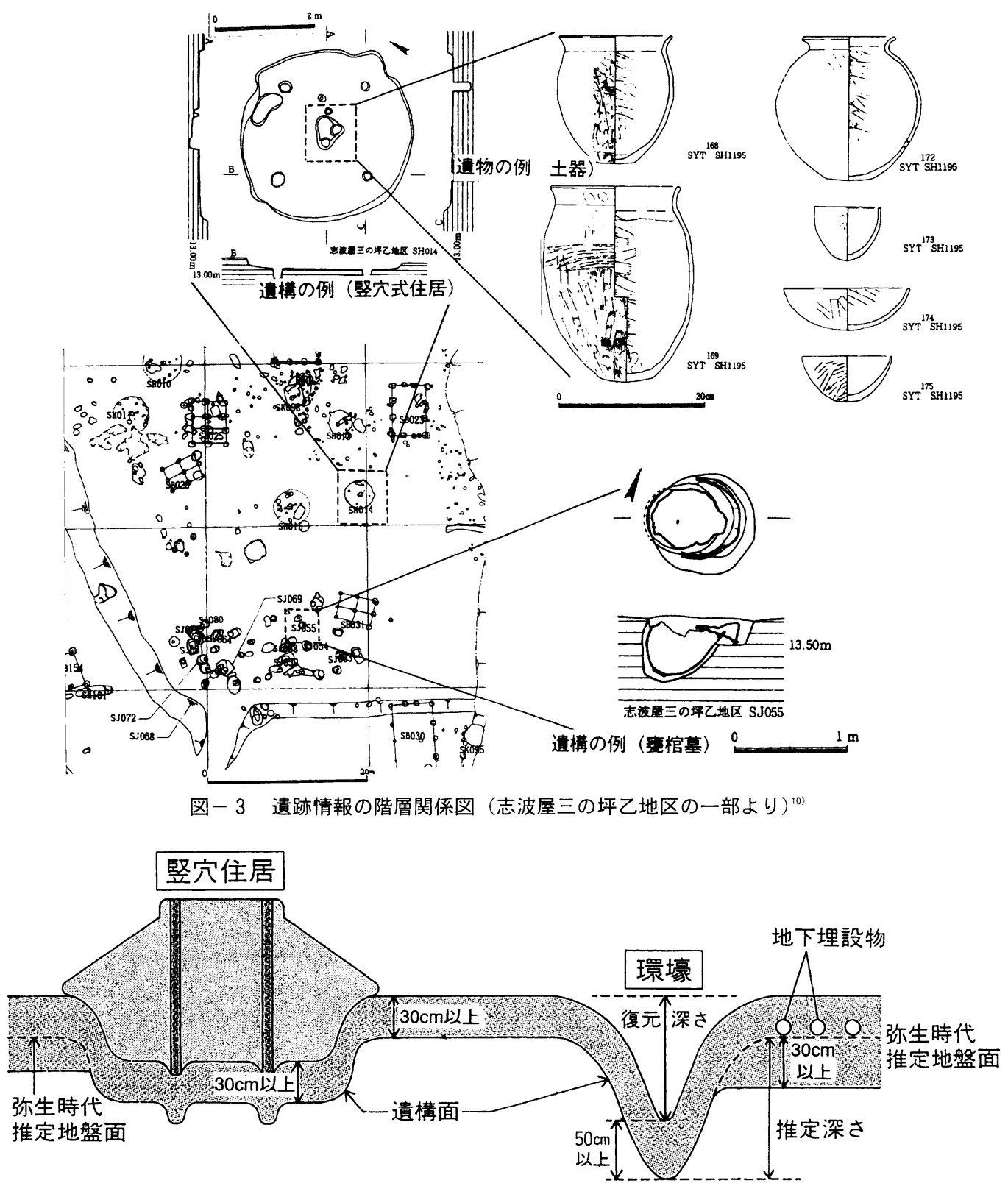

図-4 発掘再現地区の遺構保存概念図 ${ }^{12}$

地表面を表示するためのデー夕）として用いた。これは, 遺構面 に相当している。

（3）遺構面データ

\section{(i )遺構面デー夕の作成}

吉野ヶ里遺跡において作成された写真を除くすべての資料は A2 サイズの記録用紙に記録されている。一例を図 6 に示す。こ れらをA3 版フラットベッドスキャナ（EPSON ES8000）によっ てコンピュータに取り込んだ。この段階においては一枚の原図面 が左右 2 枚に分割された状態で入力されているため, 画像結合y フトゥエアである PHOTO JUGGLER (OLYMPUS) を用い, 元のサイズに再結合した。これらのデータには元の図面との突合 のためのキーコードとして「YGKVI*****」のようなファ イル名を定義してある。この場合「YGKVI」というのは「吉野 ヶ里丘陵第 VI 区」という地区名をあらわしており，それにつつ く「*****」に図面番号が入る。図面番号は図面の種類に関 係無くユニークな番号が割り振られているためファイル名が競合 することはない。ここで作成したファイルはデータベース中から
原四面データとして引き出すこともできる。また，これらの原図 面データはラスターデータであるが, ラインデータとして取り扱 うためにベクトルデータに変換した。ベクトルデータに変換する 際に問題となったのが，原図面中にある市販方眼紙の緑色べース の方眼である。これらを取り除き, 遺構デー夕のみを抽出する方 法について検討した結果, 画像解析ソフトウエアである TNTmips ver.5.7 (Micro Images Inc.およびオープン GIS) を用いることで当面の解決を得ることが可能となった。約 1670 万色で記録されている原図面データをこのソフトウェアによって 36 色に分解し, そこからべース色である緑色を含むおよそ 30 色 の要素を取り除き, 抽出されたものを中心線トレース方式でラス ターーベクター変換をかけることでベクトルデータを取り出すこ とに成功した。この状態ではデータとしての抜けや重複が見られ たため，これらをGISソフトウェアである MapInfo（MapInfo Corp. および三井造船システム技研）に取り込み，もとの原図 面デー夕と重㸚た状態で, それぞれ修正を行い, 最終的にすべて のベクトルデータを結合, 一枚のベクトルデータにしたうえで今 


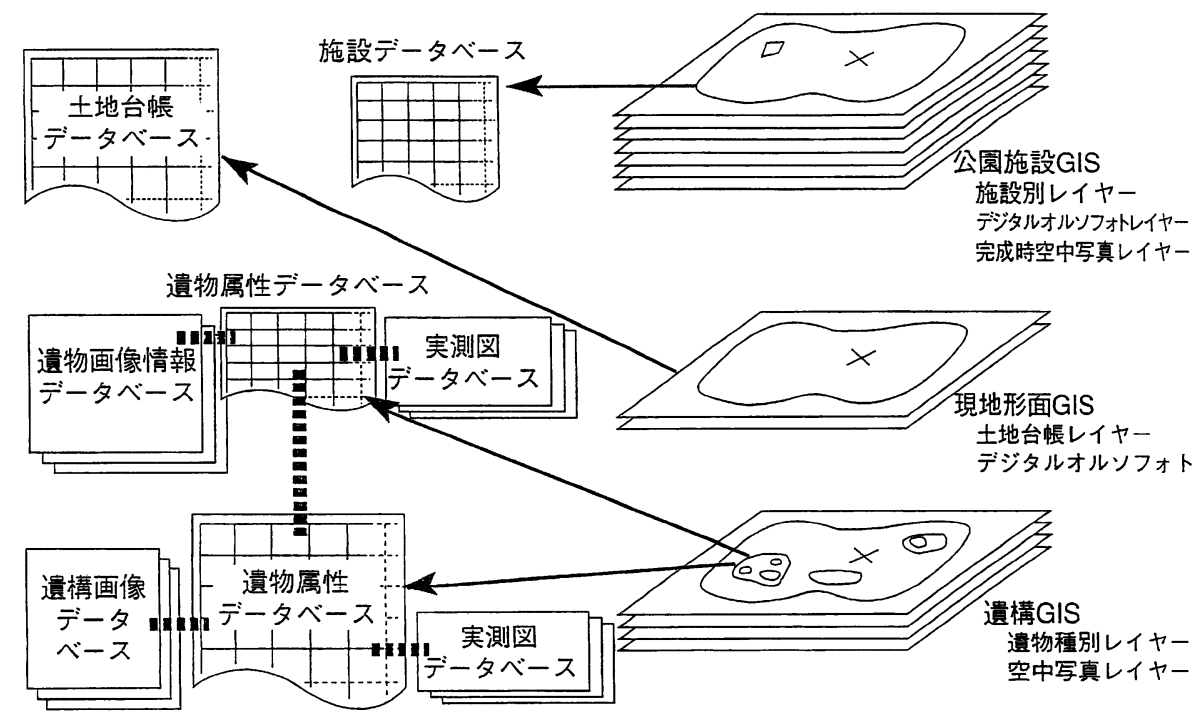

図ー5 GIS を用いたデータベース構造の概念図

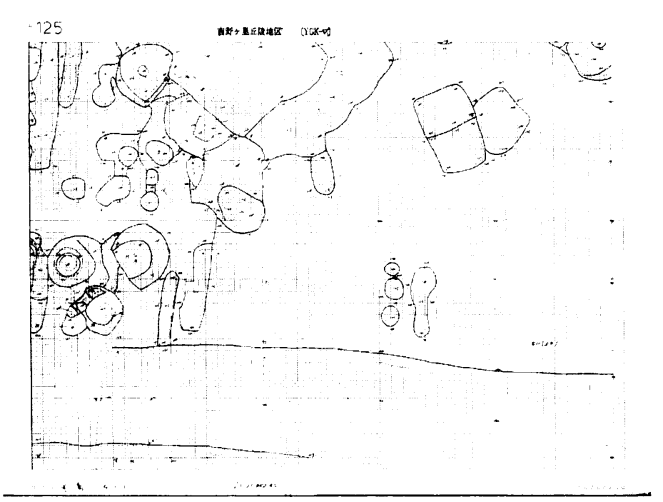

図-6 遗構記録図面の例

回利用したGIS ソフトゥェアである GRASS (US Army. CERL) で読み込める形式に変換し遺構面のデータとした。

（ii）遺構台帳のデジタルテキスト化

遺構台帳には遺構配置図に対応して, 遺構番号, 位置, 調查年 月日等が記載されている。これらに関しては表計算ソフトゥェア である Excel5.0J (Microsoft) を用いて入力し，それを夕ブ区 切りテキスト形式にした後に GRASSにインポートし, ベクター データ中の遺構データ中のポイントとリンクをはり, 属性データ として対応づけをおこなっだ788

(4) 遺物データ

(i)遺物データの作成

遺物デー夕も遺構データと同様の手法でコンピュータに取り込 んだ。ただし, 遺物デー夕の場合には同一図面中に複数の遺物が 記録されているので, 遺物台帳データにおいて, 遺物之原図面之 の対応データを記録してある。

（ii）遺物台帳のデジタルテキスト化

遗物台帳には遺構配置図に記録された遺物の位置関係に対応し て, 対応する遺構番号, 遺物番号, 発掘年月日, 年代, 器種, 遺 物状態等が記載されている。これらも遺構デー夕と同様の処理を 行った。すべての遺物データに対して属性デー夕が記録されてい るので，たとえば同じ年代で異なる層位のものを検索するといっ た使い方が可能となる。そのため，遺跡全体の年代を立体的に眺 めるようなことが簡単にできるようになり, 考古学的な見地から あ有効性を持ってくると考えられる。
6. プロトタイプシステム

（1）システム選定

目的の項で述べたようにこのシステムは, 公園の計画・設計・ 運営を行う事業者である建設省之, 遺跡の発掘・調查・情報整理・ 情報管理を行う教育委員会の双方が, 遺跡の情報を重複や漏れ, 矛盾が無く共用できるような情報構造を持たせることが必要とな る。このように複数の組織間にまたがって使われる情報をデー夕 ベース化する場合，異なる場所にある特定のコンピュータ上での み動作するスタンドアロン型のデータベースシステムであると, 情報の変更などが起こったときにシステム間において情報の同一 性を保つことが困難である。そのため，これらの条件を満たすた めには，情報発信者が情報を更新した場合，リアルタイムで利用 者屯新しい情報にアクセスできるようにする必要がある。また， この情報発信者之利用者の組織や物理的な場所が離れていること から，インターネット技術を用いたデータベースとすることがもっ とも理にかなっていると考えられる。したがって，本研究におけ るプロトタイプシステムとしてはインターネット GIS を採用す ることとした。

(2) インターネット GIS

インターネット GIS を利用することで，(1)データの維持・管 理・運用に関してサーバ側で一元的に取り扱えるため, ユーザは 常に最新情報にアクセス・利用することができる，(2)分散型デー タベースの利用によってデータの拡張が容易にできる等の利点が 考えられる。また，セキュリティ管理の面からもアクセス制限に よってある程度回避することができる。また，インターネット GIS には本システムのようサーバ側ですべての処理を行い， ク ライアントは表示だけを行うものと，サーバからはデータのみを 呼び出し，クライアント側で処理を行うものがある ${ }^{9 !} 。$ 本システ ムはクライアントマシンがどのようなマシンであっても表示が可 能であることが必要であるので, 前者の形式を採用した。このモ デルであると NetscapeNavigatar や InternetExplore といっ た HTML ブラウザが動作するWindows や Macintosh といっ たほとんどのコンピュータで利用することが可能となる。

（3）データベースの構造

今回試作したシステムはクライアント・サーバシステムを導入 し，サーバ側で遺跡情報の一元管理を行うことで利用者が複数に わたる場合でもデー夕の統一性が保たれるようにした。これらの 構成を図 7 に示す。

本システムは表示以外のすべての処理をサーバ側でおこなって 


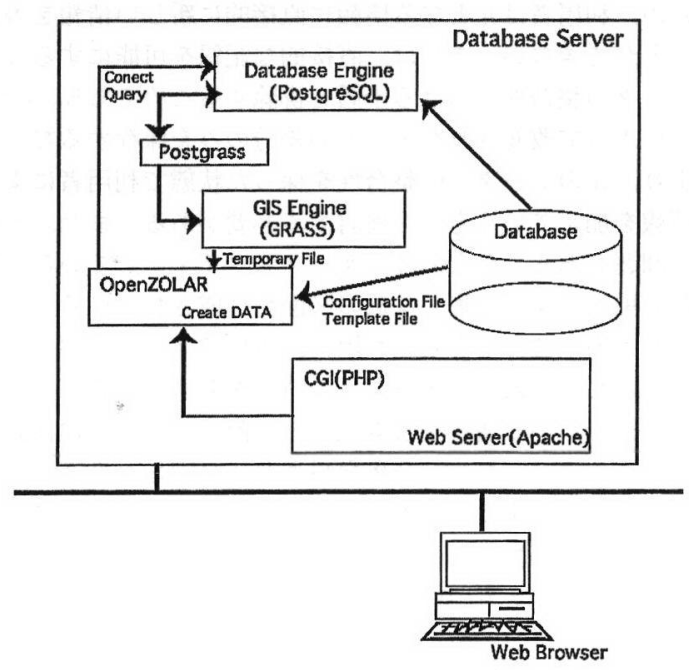

図ー7 データベースシステム概略図

いる。デー夕の発信者は, 一般のホームページと同様にデー夕を データベースにアップロードすることができるが，利用者は参照 以外は行えない。そのため複数の利用者が同時に利用していても, それらは常に完全に同一のデータであるため, 情報の漏れや重複, 矛盾が生じることなくデー夕の信頼性む保たれる。また，利用者 がデー夕を読み出したあとにサーバ側のデータが変更された場合 であっても，次の処理がおこなわれる際には置き換えられた新し いデー夕が反映されるので, 情報の発信者と利用者の間に即時性 あ保つことができる。

\section{(4) システムの構成}

サーバには PC/AT 互換機上で動作する PC-UNIX(Linux) を利用し， GIS エンジンとしてはフリーソフトウェアである GRASS を用い, データベースエンジンに PostgreSQL を用い た。この組み合わせを用いたのは Postgrass を用いることで, デー夕の連携が簡単にできるからである。クライアントとサーバ のやりとりにはWeb サーバである Apache と OpenZolar を用 いている。

本システムでは，クライアントからの要求があった場合，デー 夕ベースに格納されたデータをGRASSに送ることによってデー 夕を生成し, OpenZolarによってバイナリデータとして転送し たものをクライアントのブラウザに表示させる仕組みをとってい る。これにより, クライアント側では HTML を表示可能なブラ ウザソフトがあれば, どのようなコンピュータからでむアクセス することが可能となる。

（5）データベースの機能

本データベースにおけるデータベースファイルの構造を図 8 に 示す。クライアントの機能としては大きく分けて次の 2 点である。 ・地図情報の表示

・オブジェクト情報の表示

このうち地図データとしてはベースマップとして 2 種類, インデッ クスマップとして 1 種類, GIS レイヤーとして 2 種類のデータ の表示が可能である。これらを以下に示す。

・ベースマップ : 現地表面オルソフォトデータ・遺構面空中写真 ・インデックスマップ: 遺構配置図

・GISレイヤー：現地形面 GIS データ, 遺構 GIS データ

GIS レイヤーは単独での表示も可能であるが, ベースマップ やインデックスマップ上へ重ね合わせて表示することあできる。 また, オブジェクト情報としては遺物情報と遺構情報の 2 種類の 情報を持っている。これらは図 8 で示したように, いくつかの属 性を持った情報が含まれている。インデックスマップ上に埋め込

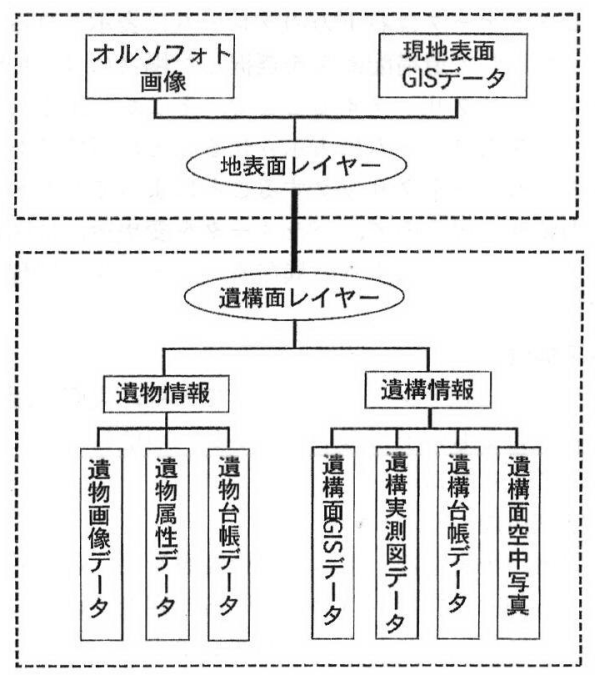

図一 8 データベースファイル構造図

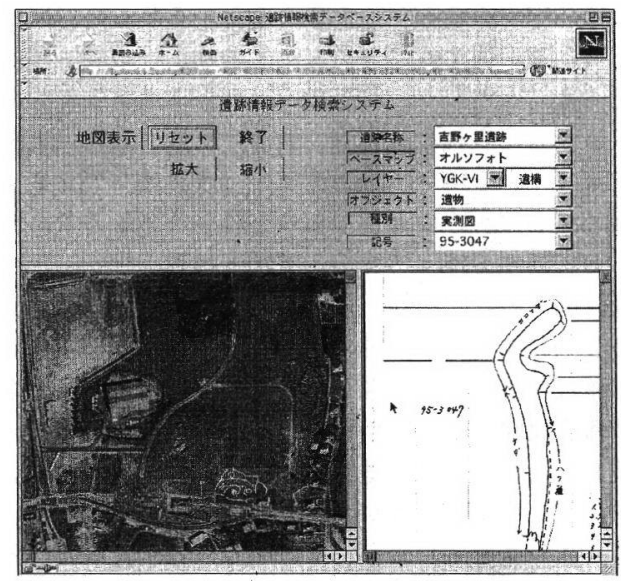

図ー 9 ブラウザによる表示例

まれたリンクによって，どこからなにが出土したかという情報を， 地図上をクリックすることで階層表示することができる。また， オブジェクト情報の整理番号等からインデックスマップの位置情 報の逆引きも可能である。なお, 公園施設 GIS に関しては未整 備である。

\section{（6）クライアントの動作}

クライアントはブラウザ（Netscape Navigatarなど）を使っ てサーバにアクセスする。それによりデータベースアクセス画面 が表示されるので, パラメータ各種を入力することでこれらの情 報を必要に応じて参照することができる。クライアントマシンの ブラウザに情報を表示した例を図 9 に示す。この例におけるパラ メー夕は上から遺跡名称・ベースマップ・レイヤー・オブジェク ト・種別・記号となっている。今回試作したシステムでは吉野ヶ 里遺跡のみを取り扱っているので遺跡名称の欄は空欄でも問題は ないが，例えば，他の遺跡において同様のデータベースを作成し， データベースのリンクを張った場合には選択が必要となる。べー スマップの闌では表示する際のベースとなるオルソフォト等を選 択し, レイヤーの闌ではエリアの指定とレイヤーの種別を選択す る。ここで地図表示ボタンを押すことによって, サーバ側でパラ メータに応じたデータを生成し, クライアントの左下方のフレー ムに地図情報を画像データとして表示する。フレーム内の地図デー 夕は上部フレームの拡大・縮小ボタンによってスケールを变えて みることができる。オブジェクト・種別の欄で選択された遺物等 
のオブジェクトデータは右下方のフレームに表示される。また, ベースマップとして遺構配置図を選択した場合には, 地図上の任 意の点をマウスでクリックすることで, そこから出土した遺物の オブジェクトを右フレームに表示させることが可能である。上部 フレームのリセットをクリックすることによってパラメータがす べて無入力状態に戻るので, パラメー夕を变更後, 地図表示ボ夕 ンをクリックすることによって異なるパラメータの情報を得るこ とが可能となる。

\section{（7）利用可能性}

本システムはプロトタイプシステムであり, 実際の運用実験は まだ行われているものではない。しかし, 可能性として, 次のよ うな利用が考えられる。

(i) 考古学的用途

現在, 発掘の現場においては, 平板測量を用いた実測図などの, 手作業による図面の作成が行われている。調査の進展に即して, これらは最初に作成されたものに順次加筆を行うことが多い。そ のため, 眓面上に調查履歴が残りにくくなっている。調査現場に おける記録の段階でデジタルデータとして取得することが簡便な 方法で可能となれば, 調査履歴を詳細なかたちで保存し, 有効な 情報として活用することができる。また，これらを GIS上のデー 夕とすることで, 個々のオブジェクトの修正・追加・関連づけが 容易に行えることとなり, 調查後の分析等にも有効に使用できる ようになると考えられる。実際, 遺構の測量や遺物の実測におい て, コンピュータを用いて数值測定を行うようなデジタル測定も 使われ始めている。このようなものを組み合わせることで, シス テムとして有効性を持ってくると考えられる。

\section{(ii) 公園計画・設計的用途}

遺跡を公園化する場合，地下に存在する遺構の破壊を防ぐため にも, 正確な位置関係を把握している必要があるため, 常に最新 の発掘情報を反映することが必要となってくる。しかし，発掘調 査が継続して行われている遺跡を公園化するにあたっては, 計画・ 設計段階において遺跡情報が発掘調査によって変化していく可能 性もある。本システムのように, 情報発信者が発掘調查と平行し て即座にデータの更新が可能となれば, 計画・設計者側は必要に 応じて, 常に最新のデー夕を入手することが可能となり, 变更な どへの対応も容易になると考えられる。

(8) システムの問題点と拡張

現システムでは必要な情報を画像情報として取り出している。
そのため, 利用者は元となる情報に直接的に新しい情報を書き加 えることができない。これは，直接的な記録を可能にすることに よるデー夕の整合性における矛盾を排除するためである。しかし, 利用者によって改変されたデー夕の差分のみを保存するなどの方 法により, 元のデータとの整合性を保った状態で利用者による新 規の情報を加えていく方法を検討する必要がある。また，デー夕 入力の問題もある。たとえば, ケーススタディとしている吉野ヶ 里遺跡の場合, すでに膨大な数の図面が作成されている。これら の図面を入力することを考えた場合, 専任のスタッフが入力のみ を行ったとしても数ヶ月オーダーの時間を要する。これに関して, 調查が進行している遺跡を公園化するに際しては, 別途検討すべ き課題であろう。しかし, 今後発見され, 公園化が推進されるも のに関しては, 効率のよい入力システムにし, 調査 $\rightarrow$ 作図 $\rightarrow$ 入力 という流れを構築することができると考えられる。そのための効 率のよい入力システムの構築も今後の検討課題である。

\section{7. まとめと今後の展望}

本システムは遺跡の遺跡情報を情報発信者と利用者相互におい て迅速に共有化し, 応用的な利活用ができるようにすることを目 的として試作した。その成果として, 紙に書かれた遺跡情報を比 較的安価な機器を用い簡便にデジタル化する手法の開発と, イン ターネットGISを利用したデータベースを用いてクライアント マシンのブラウザによって検索・表示をおこなうことに成功した。 これにより, 発信者と受信者との間におけるデー夕の共有化と, デー夕利用における一元性やデー夕更新の即時性を持たせる可能 性を開いたといえる。今後は利用者によるデー夕作成や改变に対 する対応や, 公園施設デー夕との関連づけ, 考古学研究支援のた めの分析機能などを付加することによって, さらにデー夕の広範 な利用の可能性を追求していくことが必要であるといえよう。そ れによって, 発掘時に得られた情報を公園計画や公園管理, 考古 学研究といった様々な局面で応用利用することが可能となる。そ れらの条件が達成されることによって, 吉野ヶ里歴史公園は実空 間としての公園だけではなく, 情報の仮想空間としての公園を広 く世界に発信できるようになるであろう。 謝辞

本論文の作成にあたって，佐賀県教育委員会七田忠昭氏および 建設省国営吉野ヶ里歴史公園工事事務所に資料を提供していただ いた。記して感謝したい。

\section{参考・引用文献}

1) 及川昭文 (1991): 考古学上コンピュータ シンポジウム「考古学とコンピュータ」1991吉野ヶ里遗跡をコンピュータするー

2 ）高島忠平 (1991): 吉野ヶ里遺跡の語るもの: シンポジウム「考古学とコンピュータ」 1991

3) 森本晋 (1994)：コンピュー夕活用術：『発 掘を科学する』所収、田中玩・佐原真編 $141-154$, 岩波新書

4 ）鈴木雅和・川口摩利夫・上島晃嗣 (1995) GISによる大規模公園管理支援システム 地理情報システム学会講演論文集 Vol.4/ 1995, $85-90$
5 ) 鈴木雅和・藤田英樹 -上島晃嗣・川口摩利 夫（1997）：吉野ヶ里歴史公園における GIS による情報化のフレームワーク：地理情報 システム学会講演論文集 Vol.6/1997, 163168

6 ）佐賀県教育委員会 (1995)：吉野ヶ里：佐賀 県教育委員会

7 ) 藤田英樹・川口摩利夫・上島晃嗣・鈴木雅 和 (1998)：吉野ヶ里歴史公園における発掘 情報データベースの構築：地理情報システ 么学会講演論文集 Vol.7/1998, 223-228

$8)$ 大沢裕・野中秀樹・大伴真吾・荻野信彦 (19 98）：イントラネットでの利用を目的とした 分散型地理情報システム：地理情報システ
么学会講演論文集 Vol.7/1998, 141-146 9 ) 藤田英樹・川口摩利夫・上島晃嗣・鈴木雅 和（1999）：インターネットを用いた遺跡情 報データベースシステムの構築一吉野ヶ里 歴史公園を事例として一：地理情報システ 么学会講演論文集 Vol.8/1999, 213-216

10）（社）日本公園緑地協会（1993）：吉野ヶ里遗 歷史公園基本計画策定業務報告書, 99

11）佐賀県教育委員会（1994）：吉野ヶ里遺跡発 掘調査概報 II：（財）佐賀県芸術文化育成基 金

12）建設省九州地方建設局国営吉野ヶ里歴史公 園工事事務局（1997）：『国営吉野ヶ里公園】 吉野ヶ里歴史公園リーフレット

Summary: The aim of this study is to construct the multipurpose database of park and excavation information in the Yoshinogari National Historical Park. We constructed it using internet technology operated by client/server system, in order to use for archeological research, park planning and park management. This database includes spacial and attribute data of excavation, image data and attribute data of relics and digital ortho photo of this site. This enables to unify data management on the server. The client can be operated with Web browser program. By this system, the share of excavation information is attained. Thereby application nature and simultaneity came to be obtained between park planners and archaeologists. 